\title{
Microbiological properties of root zone of coconut grown in different soil series in Sri Lanka
}

\author{
K.S.K.S. Fernando ${ }^{1}$, N.A. Tennakoon ${ }^{1}$ and S. Widanapathirana ${ }^{2}$
}

\begin{abstract}
In Sri Lanka, coconut is cultivated under diverse soil conditions of varying fertility status available in different agro-climatic zones. Although chemical and physical characteristics in some of these soils are known, their biological properties are yet to be studied. Hence the aim of this study was to determine the microbiological parameters in root zone of coconut grown in different soil series. For this study, 20 different soil series in coconut growing area were analyzed for number of total bacterial and fungal colonies, identification of bacteria and fungi, biomass $\mathrm{C}$ and $\mathrm{N} ; \mathrm{CO}_{2}$ evolution and nitrogen mineralization.

The microbiological parameters varied with the soil series. The bacterial population densities were significantly $(\mathrm{p}=0.001)$ high in Ambakelle, Kalpitiya, Rathupasa and Madampe soil series while the fungal colonies were significantly $(p=0.001)$ high in Thambarawa, Pallama, Wilatawa and Ambakelle soil series.

Only Kalpitiya, Kuliyapitiya, Gambura soil series contained biomass C more than 200 $\mathrm{mg} / 100 \mathrm{~g}$ of soils. Biomass $\mathrm{N}$ was the highest in Boralu soil series followed by Kalpitiya, Rathupasa and Gambura. Carbon diozide evolution was high in Kalpitiya, Katunayaka, Wariyapola soil series while $\mathrm{N}$ mineralization rate was high in Ambakelle, Weliketiya and Rathupasa soil series. Bacillus spp. were the dominant bacteria in all studied soil series. In addition, Micrococcus, Staphylococcus, Enterobacter, Serratia, Corynebacterium, Pseudomonas and Actinomycetes were also identified. Fungi such as Penicillium, Aspergillus and Curvularia were common in most of the soil series than other species.
\end{abstract}

Key words: Soil microbes, soils, coconut, Sri Lanka.

\footnotetext{
${ }^{1}$ Coconut Research Institute, Lunuwila, Sri Lanka.

${ }^{2}$ University of Kelaniya, Kelaniya, Sri Lanka.
} 


\section{Introduction}

In Sri Lanka, coconut is a major plantation crop and is extensively grown both as home garden small holdings and on a plantation scale in the more systematically cultivated estate sector. The coconut industry ranks high in affording employment opportunities and a means of livelihood to many. It also offers a wide scope for expanding the future Sri Lankan economy.

Soil is one of the most important factors for coconut cultivation. Coconut production is greatly influenced by the type of soil (Shanmuganathan, 1985). In Sri Lanka coconut is cultivated under different soil series of diverse fertility levels in different agro-climatic zones. Because of the scattered nature of the coconut producing areas throughout the country, the soils associated with the palm are diverse in their properties and potential (Shanmuganathan, 1985).

Although physical and chemical characteristics in most of these soils are studied, very little or no study has been made on any biological properties, especially the association of microbes. Microbiological population is a useful component in the soil which controls the decomposition of both added and existing organic matter, in soils and then subsequent release of nutrients to plants. It is known that the addition of organic materials accompanied by increase in microbial biomass, their activity and subsequent stability. Bacteria, actinomycetes and fungi are the ones most actively involved in the decay of organic materials in soils.

Therefore study of microbiological properties is very useful for the assessment of soil quality. The objectives of the present study were

i. to study the microbiological properties of different coconut growing soils and

ii. to identify the bacteria and fungi in different soil series.

\section{Methods}

\section{Site selection}

Twenty different coconut growing soils where coconut was mostly grown, within the coconut triangle were selected. Three locations were selected in each soil series, where fertilizer or manure had not been applied at least for about three years.

The selected soil series, locations, major soil types, agro-ecological regions and mean annual rainfall $(\mathrm{mm})$ are given in Table 1.

\section{Sampling procedure}

Soil samples were collected $1 \mathrm{~m}$ away from the base of the palm in the manure circle of the coconut palm (1.75 m radius from the base of the palm). For the analyses of $\mathrm{N}$ mineralization, two undisturbed core samples before incubation (TO) and after incubation (T1), respectively were taken at $0-8 \mathrm{~cm}$ depth into plastic containers. For other microbiological analysis, soils were taken from four positions in the manure circle at a depth of $0-15 \mathrm{~cm}$.

\section{Sample preparation}

Soils taken from four positions in the manure circle were sieved through a $2 \mathrm{~mm}$ mesh separated and mixed together thoroughly to get a composite sample. Fifty grams of the composite sample were weighed into a moisture can for the determination of the moisture content of soil. Rest of the fresh soils were stored at $0-4^{\circ} \mathrm{C}$ in polythene bags until microbiological analysis were commenced.

\section{Soil analyses}

Bacteria and fungi were counted to obtain their total numbers using Dilution Plate Technique under aseptic conditions on nutrient agar and potato dextrose agar media, respectively (Parkinson et al., 1971). For the identification of 
Table 1. Selected soil series, major soil types, agro-ecological regions and rainfall of the studied locations

\begin{tabular}{|c|c|c|c|c|}
\hline Soil series & Major soil type & Locations & $\begin{array}{l}\text { Agro } \\
\text { ecological } \\
\text { region }\end{array}$ & $\begin{array}{l}\text { Mean annual } \\
\text { rainfall (mm) }\end{array}$ \\
\hline Rathupasa & $\begin{array}{l}\text { Latosols and regosols } \\
\text { on old red and yellow } \\
\text { sands }\end{array}$ & $\begin{array}{l}\text { Dummaladeniya } \\
\text { Mahawewa } \\
\text { Koswadiya }\end{array}$ & $\begin{array}{l}\mathrm{IL}_{1} \\
\mathrm{IL}_{1} \\
\mathrm{IL}_{1}\end{array}$ & $\begin{array}{l}1500-1750 \\
1500-1750 \\
1500-1750\end{array}$ \\
\hline Madampe & $\begin{array}{l}\text { Latosols and regosols } \\
\text { on old red and yellow } \\
\text { sands }\end{array}$ & $\begin{array}{l}\text { Tummodara } \\
\text { Kirimetiyana } \\
\text { Madampe }\end{array}$ & $\begin{array}{l}\mathrm{IL}_{1} \\
\mathrm{IL}_{1} \\
\mathrm{IL}_{1}\end{array}$ & $\begin{array}{l}1500-1750 \\
1500-1750 \\
1500-1750\end{array}$ \\
\hline Sudu & $\begin{array}{l}\text { Latosols and regosols } \\
\text { on old red and yellow } \\
\text { sands }\end{array}$ & $\begin{array}{l}\text { Suduwella } \\
\text { Karukkuwa } \\
\text { Maradawella }\end{array}$ & $\begin{array}{l}\mathrm{IL}_{1} \\
\mathrm{IL}_{1} \\
\mathrm{IL}_{1}\end{array}$ & $\begin{array}{l}1500-1750 \\
1500-1750 \\
1500-1750\end{array}$ \\
\hline Wilattawa & $\begin{array}{l}\text { Colluvial members of } \\
\text { red yellow podzolics } \\
\text { with soft or hard } \\
\text { laterites }\end{array}$ & $\begin{array}{l}\text { Wannirasnayakapura } \\
\text { Mahagama } \\
\text { Mudalakkuliya }\end{array}$ & $\begin{array}{l}\mathrm{DL}_{1} \\
\mathrm{DL}_{1} \\
\mathrm{DL}_{1}\end{array}$ & $\begin{array}{l}800-1200 \\
800-1200 \\
800-1200\end{array}$ \\
\hline Andigama & Red yellow podzolics & $\begin{array}{l}\text { Mudalakkuliya } \\
\text { Weerakodiyana } \\
\text { Wadumunnegedara }\end{array}$ & $\begin{array}{l}\mathrm{DL}_{1} \\
\mathrm{IL}_{1} \\
\mathrm{IL}_{1}\end{array}$ & $\begin{array}{c}800-1200 \\
1500-1750 \\
1500-1750\end{array}$ \\
\hline Boralu & $\begin{array}{l}\text { Red yellow podzolic } \\
\text { with soft or hard } \\
\text { laterites }\end{array}$ & $\begin{array}{l}\text { Divulapitiya } \\
\text { Alabodagama } \\
\text { Bogamuwa }\end{array}$ & $\begin{array}{l}\mathrm{WL}_{3} \\
\mathrm{WL}_{3} \\
\mathrm{WL}_{3}\end{array}$ & $\begin{array}{l}>2250 \\
>2250 \\
>2250\end{array}$ \\
\hline Ambakelle & Alluvial soils & $\begin{array}{l}\text { Sedawatta } \\
\text { Arachchikattuwa } \\
\text { Pottukulama }\end{array}$ & $\begin{array}{l}\mathrm{DL}_{1} \\
\mathrm{IL}_{1} \\
\mathrm{IL}_{3}\end{array}$ & $\begin{array}{c}800-1200 \\
1500-1750 \\
1200-1500\end{array}$ \\
\hline Wariyapola & Non calcic brown soils & $\begin{array}{l}\text { Kobeigane } \\
\text { Awulegama } \\
\text { Wariyapola }\end{array}$ & $\begin{array}{l}\mathrm{IL}_{3} \\
\mathrm{IL}_{3} \\
\mathrm{IL}_{3}\end{array}$ & $\begin{array}{l}1200-1200 \\
1200-1500 \\
1200-1500\end{array}$ \\
\hline Maho & Non calcic brown soils & $\begin{array}{l}\text { Alahena } \\
\text { Wannigama } \\
\text { Wariyapola }\end{array}$ & $\begin{array}{l}\mathrm{IL}_{3} \\
\mathrm{IL}_{3} \\
\mathrm{IL}_{3}\end{array}$ & $\begin{array}{l}1200-1200 \\
1200-1500 \\
1200-1500 \\
\end{array}$ \\
\hline Melsiripura & $\begin{array}{l}\text { Reddish brown } \\
\text { latosolic soils }\end{array}$ & $\begin{array}{l}\text { Galwarama } \\
\text { Adirillawatta } \\
\text { Panliyadda }\end{array}$ & $\begin{array}{c}\mathrm{IL}_{1} \\
\mathrm{WL}_{2} \\
\mathrm{DL}_{1}\end{array}$ & $\begin{array}{c}1500-1750 \\
1750-2250 \\
800-1200 \\
\end{array}$ \\
\hline Warakapola & $\begin{array}{l}\text { Red yellow podzolic } \\
\text { soils }\end{array}$ & $\begin{array}{l}\text { Arangalakanda } \\
\text { Wewaldeniya } \\
\text { Neligama }\end{array}$ & $\begin{array}{c}\mathrm{WL}_{2} \\
\mathrm{WL}_{2} \\
\mathrm{WL}_{2}-\mathrm{WL}_{3}\end{array}$ & $\begin{array}{l}1750-2250 \\
1750-2250 \\
1750-2250\end{array}$ \\
\hline
\end{tabular}




\begin{tabular}{|c|c|c|c|c|}
\hline Soil series & Major soil type & Locations & $\begin{array}{c}\text { Agro ecological } \\
\text { region }\end{array}$ & $\begin{array}{l}\text { Mean annual rainfall } \\
(\mathrm{mm})\end{array}$ \\
\hline Kurunegala & $\begin{array}{l}\text { Red yellow } \\
\text { podzolic soils }\end{array}$ & $\begin{array}{l}\text { Metiyagane } \\
\text { Yaggapitiya } \\
\text { Ambanpola }\end{array}$ & $\begin{array}{c}\mathrm{IL}_{3}-\mathrm{DL}_{1} \\
\mathrm{IL}_{3}-\mathrm{DL}_{1} \\
\mathrm{IL}_{3}\end{array}$ & $\begin{array}{l}800-1200 \\
800-1200 \\
800-1200\end{array}$ \\
\hline Kuliyapitiya & $\begin{array}{l}\text { Red yellow } \\
\text { podzolic soils }\end{array}$ & $\begin{array}{l}\text { Amangalla } \\
\text { Metiyagane } \\
\text { Katupotha } \\
\end{array}$ & $\begin{array}{c}\mathrm{IL}_{1} \\
\mathrm{IL}_{3}-\mathrm{DL}_{1} \\
\mathrm{IL}_{1} \\
\end{array}$ & $\begin{array}{c}1500-1750 \\
800-1200 \\
1500-1750 \\
\end{array}$ \\
\hline Pallama & $\begin{array}{l}\text { Colluvial members } \\
\text { of red yellow } \\
\text { podzolic with soft } \\
\text { or hard lateritics }\end{array}$ & $\begin{array}{l}\text { Alabodagama } \\
\text { Divulapitiya } \\
\text { Bogamuwa }\end{array}$ & $\begin{array}{l}\mathrm{WL}_{3} \\
\mathrm{WL}_{3} \\
\mathrm{WL}_{3}\end{array}$ & $\begin{array}{l}>2250 \\
>2250 \\
>2250\end{array}$ \\
\hline Weliketiya & Sandy regosols & $\begin{array}{l}\text { Karambe } \\
\text { Kadiyamutte } \\
\text { Marawila } \\
\end{array}$ & $\begin{array}{l}\mathrm{DL}_{3} \\
\mathrm{DL}_{3} \\
\mathrm{IL}_{1} \\
\end{array}$ & $\begin{array}{c}600-1000 \\
600-1000 \\
1500-1750 \\
\end{array}$ \\
\hline Tambarawa & $\begin{array}{l}\text { Non calcic brown } \\
\text { soils }\end{array}$ & $\begin{array}{l}\text { Koorikulama } \\
\text { Kadigawa } \\
\text { Welipennagahamula }\end{array}$ & $\begin{array}{l}\mathrm{IL}_{3} \\
\mathrm{IL}_{3} \\
\mathrm{IL}_{1} \\
\end{array}$ & $\begin{array}{l}1200-1500 \\
1200-1500 \\
1500-1750 \\
\end{array}$ \\
\hline Kalpitiya & Sandy regosols & $\begin{array}{l}\text { Kurunchipitiya } \\
\text { Palakudawa } \\
\text { Nawakkaduwa }\end{array}$ & $\begin{array}{l}\mathrm{DL}_{3} \\
\mathrm{DL}_{5} \\
\mathrm{DL}_{3} \\
\end{array}$ & $\begin{array}{l}600-1000 \\
600-1000 \\
600-1000 \\
\end{array}$ \\
\hline Negombo & Sandy regosols & $\begin{array}{l}\text { Kandatoduwawa } \\
\text { Karukapana } \\
\text { Modarawella }\end{array}$ & $\begin{array}{l}\mathrm{DL}_{1} \\
\mathrm{IL}_{1} \\
\mathrm{IL}_{1}\end{array}$ & $\begin{array}{c}800-1200 \\
1500-1750 \\
1500-1750 \\
\end{array}$ \\
\hline Gambura & Red latosols & $\begin{array}{l}\text { Vijayapura } \\
\text { Bodhirajapura } \\
\text { Sirambiadiya } \\
\end{array}$ & $\begin{array}{l}\mathrm{DL}_{3} \\
\mathrm{DL}_{3} \\
\mathrm{DL}_{3} \\
\end{array}$ & $\begin{array}{l}600-1000 \\
600-1000 \\
600-1000 \\
\end{array}$ \\
\hline Katunayaka & $\begin{array}{l}\text { Latosols and } \\
\text { regosols }\end{array}$ & $\begin{array}{l}\text { Welihena } \\
\text { Ekala } \\
\text { Kadirana } \\
\end{array}$ & $\begin{array}{l}\mathrm{WL}_{4} \\
\mathrm{WL}_{4} \\
\mathrm{WL}_{4}\end{array}$ & $\begin{array}{l}>2250 \\
>2250 \\
>2250\end{array}$ \\
\hline
\end{tabular}

bacteria, pure cultures obtained from morphologically different bacterial colonies were used. They were subjected to basic morphological tests and thereafter identification was carried out using the methods given in identification of bacteria (Cowan and Steel, 1974) and Bergy's manual of systematic bacteriology (Sneath, 1986). Identification of fungi was carried out following the keys and by the microscopic examinations of the structures by using the prepared slide cultures from isolated pure colonies (Onions et al., 1981). Microbiological activity was determined by estimating the quantity $\mathrm{CO}_{2}$ evolved (Kibble, 1966). Microbial biomass carbon was estimated by the fumigation incubation method (Jenkinson and Powlson, 1976; Parkinson and Paul, 1982).
Microbial biomass nitrogen concentration was determined by chloroform fumigation technique with direct $\mathrm{K}_{2} \mathrm{SO}_{4}$ extraction (Jenkinson and Powlson, 1976) and net nitrogen mineralization was determined by shaking soils (10 g) with $2 \mathrm{M}$ $\mathrm{KCl}$ and concentrations were determined spectrophotometrically using the Rapid Flow Analyzer (Marr and Cressor, 1983).

\section{Results and discussion}

\section{Results \\ Total bacterial colonies}

The total bacterial colony counts of the soils in the manure circles of the coconut palms on different soil series are given in Table 2. Among 
the soil series, the highest bacterial colony count was obtained for the Ambakelle soil series while the lowest bacterial colony count was obtained for Kuliyapitiya soil series. Bacterial colony counts greater than $100 \times 10^{4} / \mathrm{g}$ soil were observed in few soil series and according to the decreasing order, those soil series could be arranged as Ambakelle > Kalpitiya > Rathupasa > Madampe. These soils can be considered as fertile or nutrient rich soils.

\section{Total fungal colonies}

The total fungal colony counts in different soil series are given in Table 2. In all the soils, the total fungal colony counts were greater than $10 \times 10^{3} / \mathrm{g}$ soil. In few soil series, the fungal colony counts were more than $25 \times 10^{3} / \mathrm{g}$ soil. Among them, the highest count was obtained for Thambarawa soil series followed by Pallama, Wilattawa, Ambakelle, Andigama, Weliketiya, Katunayaka and Kurunegala soil series respectively. The lowest fungal colony count was found in the Gambura soil series.

\section{Microbial biomass carbon}

Microbial biomass carbon concentrations of the soil in the manure circle of different soils are shown in Table 2. Biomass carbon of more than $50 \mathrm{mg} / 100 \mathrm{~g}$ of soils was found in all the soil series used for this study. The highest biomass $\mathrm{C}$ content occurred in Kalpitiya soil series while the lowest obtained from Sudu soil series. Microbial C content of more than 200 $\mathrm{mg} / 100 \mathrm{~g}$ of soils occurred in few soil series such as Kuliyapitiya, Gambura, Pallama and Warakapola. The differences of microbial biomass content between certain soil series were significant at $\mathrm{p}=0.05$ (Table 2).

\section{Microbial biomass nitrogen}

The microbial biomass $\mathrm{N}$ concentrations in the different coconut soils are shown in Table 2. Most of the soil series showed that biomass $\mathrm{N}$ concentrations in the manure circles were greater than $2 \mathrm{mg} / 100 \mathrm{~g}$ of soil. Among those soil series, the highest biomass $\mathrm{N}$ concentration was seen in the manure circles of Boralu soil series followed by Kalpitiya, Rathupasa, Gambura and Madampe soil series in decreasing order. The lowest biomass $\mathrm{N}$ concentration was seen in Sudu soil series which indicated that the microbial population densities were also very poor.

\section{Microbial activity $\left(\mathrm{CO}_{2}\right.$ evolution)}

The evolved $\mathrm{CO}_{2}$ quantity ( $\mu \mathrm{g} / \mathrm{g}$ soil) from the soils of the manure circles of the coconut palms in different soil series are shown in Table 2. The highest $\mathrm{CO}_{2}$ evolution was observed in Boralu soil series followed by Kalpitiya, Katunayaka, Wariyapola, Kurunegala and Kuliyapitiya soil series respectively. The lowest $\mathrm{CO}_{2}$ evolution was observed in Sudu soil series. The differences of $\mathrm{CO}_{2}$ evolution among different soil series were highly significant $(\mathrm{p}=0.001)$.

\section{Net nitrogen mineralization}

The net $\mathrm{N}$ mineralization rates in the soils of the manure circles of the coconut palms in the studied soil series are shown in Table 2 . The $\mathrm{N}$ mineralization rates observed in soil series such as Ambakelle, Weliketiya, Rathupasa, Madampe and Kalpitiya were higher than other soil series. The mineralization rates of other soil series such as Negombo, Katunayaka, Boralu and Thambarawa were low.

\section{Identification of bacteria}

The bacteria identified in different soil series are shown in Table 3. Among different types of bacteria - Bacillus spp.. Micrococci spp., Staphylococcus spp., Enterobacter spp., Serratia spp., Corynebacterium spp., Pseudononas spp., and Actinomycetes spp. were found. Most of these bacteria are commonly found in tropical soils. Bacillus spp. were the dominant bacteria in all the soil series used for this study. In addition to Bacillus species, Micrococcus lutues, Actinomycetes species, Enterobacter cloacae and Pseudomonas aerugionosa were also prominent in most of the soil series. Some bacteria were 
Table 2. Microbiological parameters in the manure circle soils in different soil series

\begin{tabular}{|c|c|c|c|c|c|c|}
\hline Soil series & $\begin{array}{c}\text { Number of total } \\
\text { bacterial } \\
\text { colonies } \\
\times 10^{4} / \mathrm{g} \text { of soil }\end{array}$ & $\begin{array}{c}\text { Number of } \\
\text { total fungal } \\
\text { colonies } \\
\times 10^{3} / \mathrm{g} \text { of } \\
\text { soil }\end{array}$ & $\begin{array}{c}\text { Microbial } \\
\text { biomass carbon } \\
\text { content } \\
\mathrm{mg} / 100 \mathrm{~g} \text { of } \\
\text { soil/ } / 7 \text { days }\end{array}$ & $\begin{array}{l}\text { Microbial } \\
\text { biomass } \\
\text { nitrogen } \\
\mathrm{mg} / 100 \mathrm{~g} \text { of } \\
\text { soil }\end{array}$ & $\begin{array}{c}\mathrm{CO}_{2} \text { evolution } \\
\mu \mathrm{g} / \mathrm{g} \text { of } \\
\text { soil/day }\end{array}$ & $\begin{array}{l}N \text { mineralization } \\
\mu \mathrm{g} / \mathrm{g} \text { of soil/day }\end{array}$ \\
\hline Wilattawa & 66 & 33 & 108.52 & 2.98 & 27.87 & 0.37 \\
\hline Andigama & 66 & 28 & 140.81 & 3.38 & 39.83 & 0.30 \\
\hline Weliketiya & 33 & 28 & 187.45 & 2.12 & 29.26 & 0.91 \\
\hline Gambura & 48 & 13 & 229.91 & 4.22 & 27.64 & 0.58 \\
\hline Kalpitiya & 195 & 23 & 247.41 & 4.77 & 96.59 & 0.70 \\
\hline Negombo & 35 & 14 & 170.85 & 2.51 & 25.15 & 0.29 \\
\hline Kuliyapitiya & 31 & 15 & 202.17 & 2.24 & 60.96 & 0.24 \\
\hline Rathupasa & 158 & 16 & 164.70 & 4.40 & 42.45 & 0.81 \\
\hline Madampe & 139 & 17 & 147.06 & 3.99 & 33.39 & 0.71 \\
\hline Sudu & 50 & 19 & 75.10 & 1.83 & 20.06 & 0.47 \\
\hline Wariyapola & 69 & 25 & 168.17 & 3.63 & 68.91 & 0.47 \\
\hline Ambakelle & 261 & 29 & 121.65 & 3.53 & 60.31 & 1.08 \\
\hline Tambarawa & 39 & 36 & 141.25 & 3.02 & 37.20 & 0.33 \\
\hline Maho & 37 & 20 & 163.62 & 2.45 & 41.92 & 0.42 \\
\hline Warakapola & 44 & 22 & 206.13 & 3.48 & 57.71 & 0.31 \\
\hline Boralu & 51 & 23 & 161.40 & 6.10 & 145.96 & 0.33 \\
\hline Katunayaka & 43 & 27 & 124.19 & 3.46 & 75.37 & 0.36 \\
\hline Pallama & 43 & 34 & 215.39 & 2.54 & 36.47 & 0.61 \\
\hline Kurnegala & 82 & 27 & 114.26 & 2.94 & 66.72 & 0.58 \\
\hline Melsiripura & 46 & 17 & 183.19 & 3.16 & 59.44 & 0.49 \\
\hline $\begin{array}{l}\text { Level of } \\
\text { significance }\end{array}$ & $*$ & $*$ & $*$ & $*$ & $*$ & $*$ \\
\hline $\operatorname{LSD}(p=0.05)$ & 11 & 3 & 14.03 & 0.59 & 7.40 & 0.52 \\
\hline CV\% & 20.8 & 18.9 & 12.1 & 34.0 & 22.4 & 7.4 \\
\hline
\end{tabular}

$*=$ Significance at $\mathrm{p}=0.05$

found to be specific to certain soil series. For example, Bacillus thuringiensis was found only in Katunayaka soil series; Aerococcus viridans in Weliketiya soil series; Bacillus pasteurii in Pallama soil series. Many bacterial species were found in soil series such as Rathupasa, Kalpitiya, Ambakelle, Boralu, Katunayaka and Melsiripura.

\section{Identification of fungi}

Fungal species identified from different soil series are shown in Table 4. Fungal species such as Penicillium, Aspergillus, Mucor, Rhizopus, Absedia, Syncephalastrum, Mortierella, Curvularia, Humicola, Ulocladium, Fusarium and Trichoderma were identified in most of soil series. Penicillium spp., Aspergillus spp., and Curvularia spp., were the most abundant fungi species among most of soils used in this study. Among the Aspergillus species, Aspergillus japonicus and Aspergillus niger were identified in all soil series while Penicillium frequentans was the most dominant species.

Some fungal species were confined to some soil series i.e. Trichoderma spp. (Pallama, Boralu and Melsiripura soil series); Ulocladium spp. (Rathupasa and Madampe soil series); Rhizopus spp. (Rathupasa, Kurunegala and Melsiripura soil series); Penicillium citreonigrum (Rathupasa and Katunayaka soil series); Penicillium oxalicum (Negombo, Warakapola and Pallama soil series); Aspergillus terreus (Weliketiya and Wariyapola soil series); Fusarium moniliforme (Wariyapola and Thambarawa soil series); Aspergillus ochraceus (Weliketiya and Gambura soil series). More fungal species were found in Rathupasa, Madampe and Ambakelle soil series. 
Table 3. Some physical and chemical parameters in the manure circle soils in different soil series

\begin{tabular}{|l|c|c|c|c|c|c|c|}
\hline \multicolumn{1}{|c|}{ Soil series } & PH & $\begin{array}{c}\text { Total } \\
\%\end{array}$ & $\begin{array}{c}\text { Available } \\
\mathrm{P} \\
\mathrm{mg} / \mathrm{kg}\end{array}$ & $\begin{array}{c}\text { Exchangeable } \\
\mathrm{K} \\
\text { meeq/100 g } \\
\text { soil }\end{array}$ & $\begin{array}{c}\text { Exchangeable } \\
\mathrm{Mg} \\
\text { meeq/100 g } \\
\text { soil }\end{array}$ & $\begin{array}{c}\text { Total C } \\
\%\end{array}$ & $\begin{array}{c}\text { Moisture } \\
\%\end{array}$ \\
\hline Wilattawa & 6.00 & 0.04 & 15 & 0.18 & 0.80 & 0.67 & 6.00 \\
\hline Andigama & 6.16 & 0.08 & 17 & 0.16 & 0.70 & 0.77 & 7.52 \\
\hline Weliketiya & 6.28 & 0.07 & 13 & 0.25 & 1.0 & 0.50 & 2.11 \\
\hline Gambura & 6.08 & 0.07 & 12 & 0.14 & 0.40 & 0.46 & 2.06 \\
\hline Kalpitiya & 5.51 & 0.05 & 15 & 0.11 & 0.42 & 0.31 & 5.32 \\
\hline Negombo & 4.68 & 0.11 & 19 & 0.05 & 0.20 & 0.59 & 1.75 \\
\hline Kuliyapitiya & 5.61 & 0.14 & 25 & 0.28 & 0.50 & 1.28 & 4.50 \\
\hline Rathupasa & 7.05 & 0.12 & 32 & 0.20 & 0.20 & 0.87 & 2.35 \\
\hline Madampe & 6.50 & 0.12 & 40 & 0.18 & 1.4 & 0.61 & 6.25 \\
\hline Sudu & 6.77 & 0.03 & 05 & 0.04 & 0.1 & 0.39 & 2.15 \\
\hline Wariyapola & 6.24 & 0.08 & 10 & 0.26 & 1.0 & 0.81 & 3.50 \\
\hline Ambakelle & 6.81 & 0.06 & 26 & 0.10 & 0.20 & 0.79 & 6.00 \\
\hline Tambarawa & 6.17 & 0.11 & 07 & 0.20 & 0.70 & 0.68 & 3.32 \\
\hline Maho & 6.00 & 0.06 & 07 & 0.15 & 0.90 & 0.88 & 9.25 \\
\hline Warakapola & 5.59 & 0.20 & 15 & 0.30 & 1.1 & 1.33 & 10.75 \\
\hline Boralu & 5.18 & 0.14 & 25 & 0.21 & 0.80 & 1.97 & 10.25 \\
\hline Katunayaka & 4.77 & 0.10 & 30 & 0.06 & 0.10 & 0.84 & 6.44 \\
\hline Pallama & 5.48 & 0.17 & 35 & 0.12 & 0.45 & 0.68 & 7.10 \\
\hline Kurnegala & 5.94 & 0.10 & 27 & 0.28 & 0.72 & 0.78 & 2.25 \\
\hline Melsiripura & 5.46 & 0.15 & 26 & 0.31 & 1.7 & 1.27 & 6.35 \\
\hline
\end{tabular}




\section{Discussion}

The bacterial colony counts were significantly high (more than $100 \times 10^{4} / 1 \mathrm{~g}$ soil) in soil series such as Ambakelle, Kalpitiya, Rathupasa and Madampe. The numbers and types of the bacteria in the soil are mostly governed by soil type and cultivation practices (Alexander, 1977). The presence of higher number of bacterial colonies in those soil series may be due to their favourable soil conditions for the growth of bacteria. The soil texture also may have a considerable effect on the number of bacterial colonies. Kalpitiya soil series is a sandy soil, Rathupasa and Madampe soil series are sandy to coarse loamy soils and Ambakelle soil series is a sandy to loamy soil. Alexander (1977) reported that sandy soils have larger pores. The distribution of bacteria in relation to soil structure may reflect different survival strategies. The

larger pores are more likely to dry out frequently so that spore-forming bacteria may be best equipped to survive in such conditions (Killham, 1994). This study clearly showed that the spore forming Bacillus were dominant in most of soils. Therefore higher number of bacteria in Rathupasa, Ambakelle, Madampe and Kalpitiya soil series were associated with higher number of Bacillus spp., in large pores. On the other hand the nutrient contents and moisture contents of these soils were high or moderate (Table 3). The high nutrient concentration promotes high bacterial population densities (Widanapathirana, 1994. Balasubramanium et al., 1972). The maximum density of microorganisms is found in regions of fairly high moisture content (Alexander, 1977). Soil series such as Kuliyapitiya, Weliketiya and Negombo have shown lower number of bacterial colonies than the other soil series. This may be due to the low moisture contents of these soils which affect the bacterial growth. These soils are poor in water holding capacity too (Somasiri, et al.,1993).

The comparison showed that a higher number of fungal colonies were seen in Thambarawa, Ambakelle, Andigama, Weliketiya,
Katunayaka and Kurunegala soil series than the other soil series. Textures of the Katunayaka, Weliketiya and Ambakelle soil series are coarse loamy, sandy and sandy loamy respectively. Large pores are found in these soils. Being organisms with long hyphae, fungi are rarely found in soil micropores (Killham, 1994). Therefore presence of large pores may be the reason for the presence of higher number of fungi in these three soils. Presence of higher fungal population in these soil series may also be due to their higher organic carbon content. For high growth of microbial population in the soils, chemical, physical and biological characteristics should be relatively favorable (Table 3 ). Under natural conditions, essential nutrients, organic matter and moisture availability are the main factors governing the microbial population densities and their activities (Tennakoon, 1998., Biswas et al., 1988., Rai and Srivastara, 1982). Among the studied soil series, the lowest fungal count was obtained by Gambura soil series. Although Gambura soil series has sandy to loamy texture which is favourable for fungal growth, both moisture content and organic carbon content is low in this soil series. This may be the reason for the observation of the lowest number of fungal colonies in Gambura soil series.

The microbial biomass $\mathrm{C}$ is a very important microbiological parameter which reflects the fertility of soil. Significantly high microbial biomass $\mathrm{C}$ concentrations (i.e. $200 \mathrm{mg} / 100 \mathrm{~g}$ of soil) were shown in few soil series such as Kalpitiya, Gambura, Pallama, Kuliyapitiya and Warakapola. In microbial biomass C, other soil organisms including algae, actinomycetes, protozoa and viruses also contribute in addition to the bacteria and fungal population of the soils. Compared to bacteria, fungi contribute more to the biomass C of the soil (Alexander, 1977). This may be one of the reasons for the observation of high concentration of biomass $\mathrm{C}$ in some of the soils. Microbial biomass $\mathrm{C}$ was more than $150 \mathrm{mg} / 100 \mathrm{~g}$ of soil in most of the soil series included in this study. These soils are biologically very active. 
Microbial biomass $\mathrm{N}$ is also a very important biological parameter in the soil. Soil series such as Boralu, Rathupasa, Gambura and Madampe have shown significantly higher ( $\mathrm{p}=$ 0.001) microbial biomass $\mathrm{N}$ contents than other soil series. The spores of the fungi, endospores of the bacteria also appeared in the soils and their nutrients such as $\mathrm{C}$ and $\mathrm{N}$ may also contribute to increase the biomass $\mathrm{C}$ as well as biomass $\mathrm{N}$ concentrations of the soils (Alexander, 1977). Therefore it is very difficult to explain the observation that the increase of bacteria and fungal population densities in some soils and that of biomass $\mathrm{C}$ and $\mathrm{N}$ in other soils. However, Kalpitiya, Rathupasa and Madampe soil series, which have shown higher number of bacterial colonies, have shown higher microbial biomass $\mathrm{N}$ contents too. Brady (1990) reported that among microorganisms, bacterial cells are in general somewhat richer in protein than fungi. The lowest biomass $\mathrm{N}$ concentration was reported in Sudu soil series of which the nutrient concentration was very poor. Generally microbial biomass $\mathrm{N}$ shows positive correlation with nutrient content of the soil (Tennakoon, 1998; Balasubramanium et al., 1972).

It has long been recognized that a greater part of the $\mathrm{CO}_{2}$ contained in the soil air is a result of the activities of soil microorganisms. Therefore, $\mathrm{CO}_{2}$ content reflects the microbial activity in the soil. $\mathrm{CO}_{2}$ evolution observed in Boralu, Kalpitiya, Katunayaka, Wariyapola, Kurunegala and Kuliyapitiya soil series was significantly high $(\mathrm{P}=0.001)$. The bacterial counts of Kalpitiya, Katunayaka and Kurunegala soil series were high. Wariyapola soil series have also shown considerable population densities of bacteria and fungi. Therefore higher $\mathrm{CO}_{2}$ evolution in these three soil series could be attributed to their high microbial population. Verma (1995) also reported that the multiplication of microorganisms takes place under favourable conditions for microbial growth, with corresponding increase in $\mathrm{CO}_{2}$ evolution. Boralu soil series has shown the highest $(\mathrm{P}=0.001) \mathrm{CO}_{2}$ evolution, although it has low number of bacterial colonies. This may be due to the presence of other organisms such as soil macrobiotes and microorganisms including actinomycetes, algae, nematodes, viruses etc. higher than bacteria and fungi. Among different soil series, Sudu soil series has shown the lowest $\mathrm{CO}_{2}$ evolution, which is a chemically, physically and biologically poor soil. There are significant interactions between water potential, temperature and nutrient supply which affect microbial activity in any soil (Tennakoon, 1998).

The soils which showed high $\mathrm{N}$ mineralization rate, i.e. Ambakelle, Weliketiya, Rathupasa, Madampe and Kalpitiya are coarse textured soil (sandy, sandy to loamy and coarse loamy). Nitrogen mineralization is generally high in sandy textured soils. This is because of the presence of low clay content in these soils. The clay content is too low to protect the soil organic matter against microbial attack (Nordmeyer and Richter, 1985). In addition to the above mentioned factors, higher aeration of these soils also enhances the microbial activity hence $\mathrm{N}$ mineralization rate. Factors such as soil type, temperature, aeration, moisture and organic matter content favourably contribute for greater $\mathrm{N}$ mineralization in these soils (Lindemann et al., 1988). Soil series such as Negombo, Katunayaka, Boralu and Thambarawa have shown lower $\mathrm{N}$ mineralization rates than the other soil series. Low $\mathrm{N}$ mineralization rates of Boralu and Thambarawa soil series (loamy to clayey and loamy textured soils) could be attributed to their fine textures. In fine textured soils, the $\mathrm{N}$ mineralization is low (Van Veen et al., 1985). Although, Negombo and Katunayaka soil series are coarse textured, those soils have shown low $\mathrm{N}$ mineralization rates. This may be due to the unfavourable factors such as low moisture content, low organic matter content, temperature etc. that affects the $\mathrm{N}$ mineralization rates other than soil texture. Negombo soil series has shown the significantly lowest moisture content among the soil series. Brady (1990) reported that nitrification is also retarded by both very low and very high moisture conditions. The optimum moisture for higher plants is also optimum for nitrification, however, appreciable nitrification occurs when the soil moisture is at or even below the wilting co-efficient. 
Soil microorganisms are of critical importance in nutrient cycling processes, and also as sources and sinks of plant nutrients. The bacteria are especially prominent among the soil microbes because of the presence of high population in a given soil and the fact they are the most abundant group, usually more numerous than the others (Alexander, 1977). The species Bacillus were the predominant bacteria isolated from every soil series in the present study. The different soil series considered in this experiment belong to various agro-climatic zones and are different from each other in physical and chemical properties. Some of the studied soil series have properties which are favourable for the microbial growth while others are not much favourable for microbial growth. But Bacillus spp. are found in both these conditions. This is because Bacillus spp. are the most numerous bacterial species in the soil and also some of the Bacillus spp. persist in unfavourable conditions by the formation of endospores that function as a part of the normal life cycle of the bacteria. These endospores often endure in adverse environments because of their great resistance to both prolonged desiccation and to high temperature (Alexander, 1977).

In addition to Bacillus, some other genera such as Micrococcus, Staphylococcus, Enterobacter, Serratia, Corynebacterium, Pseudomonas, Aerococcus, Eriwinia and Actinomycetes were also found. These types of bacteria are capable of utilizing various organic compounds present in soil i.e. Pseudomonas and Bacillus are capable of utilizing cellulose, hemicellulose, starch and proteins, Serratia and Micrococcus have the utilizing ability of starch; Corynebacteria have the ability to utilize proteins. Bacillus and Pseudomonas have the phosphate solubilization ability (Verma, 1995; Wani and Lee, 1995).

Some soil series i.e. Rathupasa, Kalpitiya, Ambakelle, Boralu, Katunayaka and Melsiripura have shown more bacterial species than the other soil series. This may be due to the presence of favourable conditions for microbial growth. Most of those soils have shown higher amount of organic C content compared to other soil series. Environmental conditions that affect the density and composition of the bacterial flora and nonbiological factors can frequently alter the community and its biochemical potential. The primary environmental variable influencing soil bacteria include moisture, aeration, temperature, organic matter, acidity and inorganic nutrient supply (Alexander, 1977; Ramaswami and Rai, 1973; Shantharam et al., 1973). Fungi are also an important biological factor in the soil as bacteria. Among the identified fungi, Penicillium, Aspergillus and Curvularia were common than the other fungi. Cosico (1994) reported that Penicillium and Aspergillus belongs to commonly found genera of fungi in soils. Fungi such as Mucor, Rhizopus, Absedia, Suncephalastrum, Mortierella, Humicola, Ulocladium and Trichoderma were also found in this study. Medoza and Joson (1986) identified Aspergillus terreus as one of the most cellulose utilizing fungi. Some of the important hemicellulose decomposers include fungi such as Aspergillus and Trichoderma. Some soil series have shown more fungal species. This may be due to favourable environmental conditions of such soils for the growth of fungi. Apart from the soil factors and the environmental factors, the root exudates etc. are also affected to the increasing soil microorganisms densities and their activities in the soil (Killham, 1994).

\section{Conclusion}

High values of most of the microbiological parameters in soil series such as Ambakelle, Kalpitiya, Rathupasa and Madampe indicate favourable conditions for coconut. Some kinds of bacteria and fungi are specific to certain soils. Bacillus spp. were the dominant bacteria in all soils. Fungal species such as Penicillium, Aspergillus and Curvularia were common in most of the soil series. The decreasing order of the studied microbiological parameters in the soil series was as follows.

(i) Number of total bacterial colonies : Ambakelle > Rathupasa > Madampe

(ii) Number of total fungal colonies : Tambarawa > Pallama > Ambakelle 
(iii) Number of bacterial species :

Rathupasa > Kalpitiya > Ambakelle > Boralu > Melsiripura

(iv) Number of fungal species : Rathupasa > Madampe > Katunayaka

(v) Microbial biomass carbon : Kalpitiya $>$ Gambura $>$ Pallama

(vi) Microbial biomass nitrogen : Katunayaka $>$ Kalpitiya $>$ Rathupasa

(vii) $\mathrm{CO}_{2}$ evolution : Boralu > Kalpitiya > Katunayaka

(viii) Net nitrogen mineralization : Ambakelle > Weliketiya > Kalpitiya

\section{References}

Alexander, M. 1977. Introduction to Soil Microbiology. John Willey \& Sons, New York. pp.36-51, 128-147, 251-256.

Balasubramanium, A., Shantharam, M.V., Sardeshpande, T.S. and Rangaswamy, G. 1972. Studies on certain microbiological properties of the old permanent manorial plots at Coimbatore. Madras Agric. J. 59: 443-448.

Biswas, T.D. and Khosla, B.K. 1971. Building up of organic matter status of soil and its relation to soil physical properties. In: Proceedings of the International Symposium on Soil and Fertilizer Evaluation, India, pp. 831-842.

Brady, N.C. 1990. The Nature and Properties of Soils. 10th edition. Macmillon Publishing Company. Inc., New York.

Cosico, W.C. 1994. Are microbial innoculants necessary in composting. Philippine Agricul. 77(1): 67-76.

Cowan, S.T. and Steel, 1974. Identification of Medical Bacteria. Cambridge University Press.

Jenkinson, D.S. and Powlson, D.S. 1976. The effects of biocidal treatments on metabolism in soil. I. Fumigation with chloroform. Soil Biol. Biochem. 8: 209-213.

Kibble, R.A. 1966. Physiological activity in pinewood soil. $\mathrm{PhD}$ Thesis. University of Livepool, U.K. Studying the ecology of soil microorganisms, I.B.P. Handbook No. 19, International Biological Programme, London, WWI.

Killham, K. 1994. Soil Ecology. Cambridge University Press. pp. 5, 16, 40-46, 71-75.

Lindemann, W.C., Connell, G. and Urquhart, N.S. 1988. Previous sludge addition effects on nitrogen mineralization in freshly amended soil. Soil Sci. Soc. American J. 52: 109-117.

Marr, I.L. and Cressor, M.S. 1983. Environmental Chemical Analysis. International Text Book Company, New York.

Medoza, N.S. and Joson, L.M. 1986. Isolation, selection and characterization of cellulose degrading fungi. Phillippine J. Sci. 115(1): $31-41$.

Nordmeyer, H. and Richter, J. 1985. Incubation experiments on $\mathrm{N}$ mineralization in loam \& sandy soils. Plant and Soil 83: 433-445.

Onions, A.H.S., Allsopp, D. and Eggins, H.O.W. 1981. Smith's Introduction to Industrial Mycology. (Seventh edition). Edward Arnold Publishers Limited, 41, Bedford Square, London, WCLB 3DQ.

Parkinson, D., Gray, T.R.G. and Williams, S.T. 1971. Methods for studying the ecology of soil microorganisms, p. 36-51, 64-66, 71101. IBP Handbook No. 19. International Biological Programme, London, NW1.

Parkinson, D. and Paul, A.E. 1982. Microbial biomass. Cited in method of soil analysis part 2, chemical and microbiological properties. Agronomy Monograph No. 9, pp. 821-830. 
Rai, B. and Srivastara, A.K. 1982. Microbial decomposition of leaf litter as influenced by fertilizers. Plant and Soil 66(2): 195204.

Ramaswami, P.R. and Raj, D. 1973. Studies on certain physico-chemical and microbiological properties of the old permanent manorial plant at Coimbatore. Madras Agric. J. 60(8): $1001-1005$.

Shanmuganathan, R.T. 1985. Soils of the Coconut Areas. Cocon. Bull. 2(1): 8-9.

Shantaram, M.V; Balasubramanium, A. and Rangaswami, G. 1973. Sequence of soil microflora decomposing maize straw and stubble added to a red sandy loam soil. Madras Agric. J. 60(8): 1074-1079.

Sneath, P.H.A. 1986. Bergy's Manual of Systemic Bacteriology 2: 1104-1125.

Somasiri, L.L.W., Nadarajah, N., Amarasinghe, L. and Gunethilaka, H.A.J. 1993. Land Suitability Assessment of Coconut Growing Lands in the Coconut Triangle. Coconut Research Institute, Lunuwila, Sri Lanka, pp. $1-5$.

Tennakoon, N.A. 1998. Study of the Microbiological and other Related Properties of Different Coconut Soils. CARP Research Terminal Report. Coconut Research Institute, Sri Lanka. pp. 70-73.

Van Veen, J.A., Ladd, J.N. and Amato, M. 1985. Turnover of carbon and nitrogen through the microbial biomass in a sandy loam and a clay soil incubated with $\left[{ }^{14} \mathrm{C}(\mathrm{U})\right]$ glucose and $\left[{ }^{15} \mathrm{~N}\right] \quad\left(\mathrm{NH}_{4}\right) 2 \mathrm{SO}_{4}$ under different moisture regimes. Soil Biol. \& Biochem. 17: 747-756.

Verma, L.N. 1995. Conservation and efficient use of organic sources of plant nutrients. In: Organic Agriculture, (P.K. Thampan Ed.) Peekay Tree Crops Development Foundation Cochin - 682020, Gandhi Nagar, Kerala, India.
Wani, S.P. and Lee, K.K. 1995. Microorganisms as biological inputs for sustainable agriculture. In: Organic Agriculture, (P.K. Thampan Ed.). Peekay Tree Crops Development Foundation Cochin - 682020, Gandhi Nagar, Kerala, India.

Widanapathirana, S. 1994. Soil Quality. The role of microorganisms. Proceedings of the Workshop on Soil Quality - Assessment of Degradation and Restoration. Sri Lanka Foundation Institute, Colombo, 23-25 March. 